\title{
Influence of Culinary Treatment on Soriz Mineral Elements (Sorghum oryzoidum)
}

\author{
Rodica Siminiuc*, Lidia Coșciug \\ Department of Food and Nutrition, Faculty of Food Science, Technical University of Moldova, Chisinau, Republic of Moldova \\ Email: *rodica.siminiuc@adm.utm.md, lidia.cosciug@toap.utm.md
}

How to cite this paper: Siminiuc, R. and Coșciug, L. (2022) Influence of Culinary Treatment on Soriz Mineral Elements (Sorghum Oryzoidum). Food and Nutrition Sciences, 13, 78-84.

https://doi.org/10.4236/fns.2022.131008

Received: December 28, 2021

Accepted: January 25, 2022

Published: January 28, 2022

Copyright $\odot 2022$ by author(s) and Scientific Research Publishing Inc. This work is licensed under the Creative Commons Attribution International License (CC BY 4.0).

http://creativecommons.org/licenses/by/4.0/

\begin{abstract}
Soriz (Sorghum oryzoidum) is a relatively new cereal of hybrid origin obtained at the Research Institute for Maize and Sorghum of Moldova. This paper presents and analyzes the results of the study of essential minerals content $(\mathrm{K}, \mathrm{Na}, \mathrm{Ca}, \mathrm{P}, \mathrm{Mg}, \mathrm{Fe})$ in native and hulled sorghum grains and their changes under the effect of hydrothermal treatment. The results show that the sorghum grains are a good source of essential minerals, especially of $\mathrm{K}, \mathrm{P}$ and $\mathrm{Mg}$ and are less rich in $\mathrm{Ca}, \mathrm{Na}$ and $\mathrm{Fe}$. The experimental data have demonstrated that the technological process applied to obtain hulled sorghum leads to a considerable decrease in minerals content. Culinary treatment had a greater impact on the $\mathrm{K}$ content and lower on $\mathrm{P}$ and $\mathrm{Mg}$ content. The results will be used to optimize the parameters of raw material processing and culinary treatment with the aim of minimizing the mineral loss as well as for the nutritional value balance of soriz sorghum dishes.
\end{abstract}

\section{Keywords}

Whole Grains of Soriz, Hulled Sorghum Grains, Essential Minerals, Culinary Treatment

\section{Introduction}

Cereals and food derivatives from cereals are the staple food of the population all over the world, only the crops being different from one country to another [1] [2]. Diversifying the range of cereals is highly relevant in the context of nutritionists' recommendations to increase the intake of foods rich in complex carbohydrates in combination with decreased lipid intake, in order to reduce the risk of cardiovascular disease and other metabolic diseases [3] [4] which are the leading causes of death in European countries.

Cereal grains are the major source of dietary nutrients in the world. However, a large part of them is lost after processing (peeling, crushing, grinding, mois- 
turizing, boiling, frying, expanding, etc.). The loss of mineral elements in the process of decortication depends on the types of cereals, their sizes, the degrees of peeling, etc [5].

The content of mineral elements is also influenced by culinary technological processes, which refer to the ability of cereals to boil in the shortest possible time, accompanied by the improvement of organoleptic qualities.

Prior to the culinary treatment, the cereals are subjected to technological processes of primary processing such as: sorting (sometimes sifting) and washing. The content of dry substances in the water after washing is: starch-about $41 \%$, nitrogen-about $33 \%$ and sugar-about $13 \%$. Some research on the influence of hydration (for 24 hours) of whole grains (corn, sorghum, rice, etc.) on the content of iron, zinc and phytates has shown that during hydration in the water passes a considerable amount of iron and less zinc [6].

Knowing the impact of processing on cereals could contribute to the selection of technological processes with a tolerant effect on nutrients, which will increase their accessibility and, respectively, will contribute to increasing public health.

Soriz (Sorghum oryzoidum) is a hybrid of sorghum that is characterized by glassy endosperm, similar to rice. It was obtained at the Institute for Scientific Research for Maize and Sorghum in the Republic of Moldova, by crossing Sudan grass ( $S$. sudanense) and sorghum bicolor (S. bicolor) [7] [8] [9].

The advantages of this crop have many; sorghum is a local crop with high productivity, resistant to drought and high ambient temperatures, a source of macro- and micronutrients with high nutritional value. An important feature of soriz is the absence of gluten, which makes it an optimal alternative in the diver. Diversification of gluten-free products is a relevant and popular field of research, especially for the Republic of Moldova [7] [10] [11].

The paper presents and analyzes the results of the research of the content of essential mineral elements ( $\mathrm{K}, \mathrm{Na}, \mathrm{Ca}, \mathrm{P}, \mathrm{Mg}, \mathrm{Fe}$ ) in whole grains of soriz and hulled soriz and the modification of their content in the culinary treatment.

The results obtained are useful for optimizing the manufacturing process and technological processing of sorghum grains and groats in order to minimize losses of mineral elements, evaluation and nutritional balance of sorghum-based preparations.

\section{Materials and Methods}

\subsection{Materials}

Whole grains of soriz and hulled soriz "Alimentar 1", purchased at the Institute of Plant Protection and Organic Agriculture of the Academy of Sciences of Moldova, were used as research material. The following materials were used for research (Table 1).

\subsection{Methods}

The ash content was determined after the removal of organic matter by dry 
Table 1. Materials used in the paper for dosing mineral elements.

\begin{tabular}{|c|c|c|}
\hline No. & Raw materials used for determinations & Dry matter, $\%$ \\
\hline 1. & Whole grains of soriz & 87.6 \\
\hline 2. & $\begin{array}{l}\text { Boiled whole grains (without prior hydration) } \\
\text { Boiling time }-115 \pm 5 \text { minutes }\end{array}$ & 29.4 \\
\hline 3. & $\begin{array}{l}\text { Whole grains cooked after pre-hydration } \\
\text { Hydration time } 8 \text { hours. } \\
\text { Boiling time }-85 \pm 5 \text { minutes }\end{array}$ & 33.6 \\
\hline 4. & Raw dehulling grains & 87.2 \\
\hline 5. & $\begin{array}{c}\text { Boiled dehulling grains } \\
\text { Boiling time }-40 \pm 5 \text { minutes }\end{array}$ & 21.0 \\
\hline
\end{tabular}

ashing according to AOAC (2006) official method [12] [13]. Initially, the weight of clean and dried crucible was measured (W1) and a $5 \mathrm{~g}$ of sample (W2) was added and charred in the hot plate under the hood. The charred sample was placed in a muffle furnace and ignited at $550^{\circ} \mathrm{C}$ for $5 \mathrm{~h}$ until the sample became white/gray. The crucibles and their content were cooled in a desiccator and weighed (W3) to determine ash content.

Minerals content analysis was determined according to AOAC, (2000) [12]. Sodium $(\mathrm{Na})$ and potassium $(\mathrm{K})$ concentrations were determined by using the standard flame emission photometer; phosphorus $(\mathrm{P})$ was determined colorimetrically by vanadate-molybdate method procedure. Calcium $(\mathrm{Ca})$ and iron $(\mathrm{Fe})$, concentrations were measured by atomic absorption spectrophotometer.

\section{Results}

Minerals are considered to be essential in human nutrition [14] [15]. The concentration of mineral elements in cereals and cereal derivatives varies depending on genotypic and environmental influences, as well as the degree of technological processing.

The results obtained showed that whole grains of soriz have an important source of K (393.84 mg/\%), P (307.65 mg/\%) and Mg (160.26 mg/\%), comparable to cereals commonly used in food such as wheat, rye, buckwheat, rice, in which, according to the chemical composition of food, the content of these elements is within the following limits: $\mathrm{K}(328-425 \mathrm{mg} / \%), \mathrm{P}(200-453 \mathrm{mg} / \%)$, $\mathrm{Mg}$ (96- $153 \mathrm{mg} / \%)$. It is also noticeable the low content of $\mathrm{Ca}(13.89 \mathrm{mg} / \%), \mathrm{Fe}$ $(4.2 \mathrm{mg} / \%)$ and $\mathrm{Na}(1.2 \mathrm{mg} / \%)$ in soriz grains, which is characteristic, and for the cereals mentioned above, in which these elements are contained within the following limits: $\mathrm{Ca}(12-92 \mathrm{mg} / \%), \mathrm{Fe}(2.6-12.1 \mathrm{mg} / \%)$, and $\mathrm{Na}(0.9-89.0$ $\mathrm{mg} / \%)$.

Boiling whole soriz grains (without prior hydration) reduces the content of potassium (23.36\%), phosphorus (13.0\%) and magnesium (8.78\%) [16] [17].

Prior hydration of soriz grains in water for 8 hours before boiling slightly reduced the final losses of $\mathrm{P}$ and $\mathrm{Mg}$ by $3.13 \mathrm{mg} / \%$ and $7.0 \mathrm{mg} / \%$, respectively, pos- 
sibly due to the shorter heat treatment period until the product is fully penetrated, but increased by about $3 \mathrm{mg} / \%$ the loss of potassium, which has a higher solubility than the first and can possibly diffuse into the water, including in the process of softening the grains.

Preliminary hydration of the grains had a more tolerant impact on most of the minerals studied. Thus, the Fe content of hydrated and boiled soriz grains is 3.48 $\mathrm{mg} / \%$, and in cooked grains without hydration $-3.22 \mathrm{mg} / \%$, which is a reduction of $17.1 \%$ and $-23.3 \%$ respectively, compared to native samples. The boiling of the grains contributed to the increase of the share of $\mathrm{Ca}$ (by 15.80\%) and $\mathrm{Na}$ (by $41.66 \%$ ), compared to the native grains, and the share of $\mathrm{Ca}$ and $\mathrm{Na}$ in the boiled grains after prior hydration increased by $67.97 \%$ and $70.83 \%$ respectively in hydrated and boiled grains.

During the boiling process, the redistribution of the substances in the product takes place through mass transfer and diffusion processes. Thus, the increase in the mass fraction of calcium in the dry mass of boiled sorghum grains could be explained by the low solubility of $\mathrm{Ca}$ and sodium, possibly by locating this element in the inner layers of the grain, which slows down the diffusion of $\mathrm{Na}$ into the environment.

The nutritional value of cereals depends a lot on their processing methods (peeling, crushing, grinding, hydrothermal treatment, etc.) [18] [19].

It has been established that the content of mineral elements investigated in native soriz hulled grains is lower than in grains, with the exception of Na. Thus, the dehulling of the grain led to a decrease in the content of $\mathrm{K} 2.5$ times, $\mathrm{P}-2.9$ times, $\mathrm{Mg}$-de 3.7 times, $\mathrm{Ca}-\mathrm{de} 2.4$ times and $\mathrm{Fe}-3.2$ times. This can be explained by the concentration of the mentioned mineral substances mainly in the upper layers of the grain which are removed in the process of peeling the grains. The potassium content in dehulled grains is slightly higher than in whole grains (1.2 times), which is possibly explained by the location of this element in the inner layers of the soriz grain.

In sorghum hulled grains, as in whole grains, the major part of the mineral elements is represented by $\mathrm{K}(157.4 \mathrm{mg} \%), \mathrm{P}(104.78 \mathrm{mg} / \%)$ and $\mathrm{Mg}(43.53$ $\mathrm{mg} / \%)$, and $\mathrm{Ca}, \mathrm{Fe}, \mathrm{Na}$ in insignificant amounts, respectively $5.90 ; 1.33$ and 1.27 $\mathrm{mg} / \%$.

Boiling the husked grains led to an even more significant reduction in the share of potassium $(78.82 \%)$ and phosphorus $(9.74 \%)$ in the finished product. The mass fraction of the other mineral elements $(\mathrm{Ca}, \mathrm{Mg}, \mathrm{Fe})$ in the dry mass of the cooked husked grains has increased, which could be explained by their lower solubility in relation, for example, to that of potassium.

Analyzing the mineral content of whole grains and peeled boiled soriz grains (Table 2), it can be seen that whole grains are a more valuable source of potassium (301.87 - $290.17 \mathrm{mg} / \%$ ), whose content is 9 times higher than in dehulled grains $(33.3 \mathrm{mg} / \%)$, and the phosphorus and magnesium content is higher in whole grains of boiled soriz (267.69 - $277.3 \mathrm{mg} / \%$ and $146.19-157.41 \mathrm{mg} / \%$ ) compared to boiled hulled grains $(94.57 \mathrm{mg} / \%$ and $55.28 \mathrm{mg} / \%)$. The content of 
Table 2. The impact of dehulling and hydrothermal treatment on some mineral elements of soriz, $\mathrm{mg} / \%$ dry matter.

\begin{tabular}{|c|c|c|c|c|c|c|}
\hline \multirow{2}{*}{\multicolumn{2}{|c|}{$\begin{array}{l}\text { Mineral } \\
\text { elements }\end{array}$}} & $\begin{array}{l}\text { Whole } \\
\text { grains } \\
\text { of soriz }\end{array}$ & $\begin{array}{l}\text { Boiled whole } \\
\text { grains (without } \\
\text { prior hydration) }\end{array}$ & $\begin{array}{c}\text { Whole grains } \\
\text { cooked after } \\
\text { pre-hydration }\end{array}$ & $\begin{array}{c}\text { Raw } \\
\text { dehulling } \\
\text { grains }\end{array}$ & $\begin{array}{c}\text { Boiled } \\
\text { dehulling } \\
\text { grains }\end{array}$ \\
\hline & & \multicolumn{5}{|c|}{$\mathrm{mg} / \%$} \\
\hline 1 & $\mathrm{~K}$ & $393.84 \pm 0.02$ & $301.87 \pm 0.01$ & $290.17 \pm 0.02$ & $157.40 \pm 0.01$ & $33.33 \pm 0.01$ \\
\hline 2 & $\mathrm{Na}$ & $1.20 \pm 0.01$ & $1.70 \pm 0.01$ & $2.05 \pm 0.02$ & $1.27 \pm 0.03$ & $1.31 \pm 0.04$ \\
\hline 3 & $\mathbf{P}$ & $307.65 \pm 0.02$ & $267.69 \pm 0.08$ & $277.30 \pm 0.03$ & $104.78 \pm 0.02$ & $94.57 \pm 0.01$ \\
\hline 4 & $\mathrm{Ca}$ & $13.89 \pm 0.05$ & $16.09 \pm 0.01$ & $23.33 \pm 0.01$ & $5.90 \pm 0.06$ & $24.52 \pm 0.01$ \\
\hline 5 & $\mathrm{Mg}$ & $160.26 \pm 0.01$ & $146.19 \pm 0.01$ & $157.41 \pm 0.05$ & $43.53 \pm 0.01$ & $55.28 \pm 0.01$ \\
\hline 6 & $\mathrm{Fe}$ & $4.20 \pm 0.03$ & $3.22 \pm 0.02$ & $3.48 \pm 0.02$ & $1.33 \pm 0.01$ & $2.13 \pm 0.01$ \\
\hline
\end{tabular}

sodium, calcium and iron is nutritionally insignificant and does not differ significantly in boiled sorghum grains and crepes.

\section{Conclusions}

Based on the results of the research, the following conclusions can be drawn:

Whole grains of soriz, like other traditional cereals in the regional diet (wheat, rye, buckwheat, rice), are an important source of potassium, phosphorus and magnesium, but are poor in some essential mineral elements in human nutrition such as calcium and iron.

The shelling of sorghum beans has a negative impact on the content of mineral elements.

Boiling whole grains with pre-hydration has a more tolerant impact on the mineral content and could be recommended as a preliminary step in the cooking process of cereals.

\section{Funding}

This research was funded by state project "Personalized Nutrition and Intelligent Technologies for My Well-Being”, No. 20.80009.5107.10, running at Technical University of Moldova and Contributions regarding nutritional eradication of gluten consumption diseases, No. 21.00208.5107.06/PD.

\section{Conflicts of Interest}

The authors declare no conflicts of interest regarding the publication of this paper.

\section{References}

[1] Sarwar, M.H., et al. (2013) The Importance of Cereals (Poaceae: Gramineae) Nutrition in Human Health: A Review. Journal of Cereals and Oilseeds, 4, 32-35. https://doi.org/10.5897/JCO12.023 
[2] Laskowski, W., Górska-Warsewicz, H., Rejman, K., et al. (2019) How Important Are Cereals and Cereal Products in the Average Polish Diet? Nutrients, 11, Article No. 679. https://doi.org/10.3390/nu11030679

[3] Oso, A.A. and Ashafa, A.O. (2021) Nutritional Composition of Grain and Seed Proteins. In: Jimenez-Lopez, J.C., Ed., Grain and Seed Proteins Functionality, IntechOpen, London, Article No. 97878. https://doi.org/10.5772/intechopen.97878

[4] Senthil, S.P.A. (2015) Effect of Hydrothermal Treatment on the Nutritional and Functional Properties of Husked and Dehusked Buckwheat. Journal of Food Processing \& Technology, 6, Article No. 461.

[5] Luithui, Y., Nisha, R.B. and Meera, M.S. (2019) Cereal By-Products as an Important Functional Ingredient: Effect of Processing. Journal of Food Science and Technology, 56, 1-11. https://doi.org/10.1007/s13197-018-3461-y

[6] Ratushnii, D.C., Saranov, B.D. and Kovaliov, N.I. (2003) Technology of Catering Products. Physico-Chemical Processes Occurring in Food Products during Their Culinary Processing.

[7] Chirsanova, A., Reșitca, V., Siminiuc, R., et al. (2021) Innovative Food Products. Thenica-UTM, Chisinau. https://doi.org/10.5281/ZENODO.5563412

[8] Galaiev, O.V., Shevchuk, G.I., Dudchenko, V.V. and Syvolap, I.M. (2011) Molecular Genetic Analysis of Soriz Genome (Sorghum oryzoidum). Cytology and Genetics, 45, Article NO. 208. https://doi.org/10.3103/S0095452711040049

[9] Siminiuc, R. and T,urcanu, D. (2020) The Impact of Hydrothermal Treatments on Technological Properties of Whole Grains and Soriz (Sorghum oryzoidum) Groats. Food and Nutrition Sciences, 11, 955-968. https://doi.org/10.4236/fns.2020.1110067

[10] Kulamarva, A.G., Sosle, V.R. and Raghavan, G.S.V. (2009) Nutritional and Rheological Properties of Sorghum. International Journal of Food Properties, 12, 55-69. https://doi.org/10.1080/10942910802252148

[11] Siminiuc, R. and Țurcanu, D. (2020) Certain Aspects of Nutritional Security of People with Gluten-Related Disorders. Food and Nutrition Sciences, 11, 1012-1031. https://doi.org/10.4236/fns.2020.1111072

[12] Horwitz, W. (2006) Official Methods of Analysis of AOAC International. 18th Edition, AOAC International, Gaithersburg, MD.

[13] Poitevin, E. (2016) Official Methods for the Determination of Minerals and Trace Elements in Infant Formula and Milk Products: A Review. Journal of AOAC INTERNATIONAL, 99, 42-52. https://doi.org/10.5740/jaoacint.15-0246

[14] Aslam, M.F., Ellis, P.R., Berry, S.E., et al. (2018) Enhancing Mineral Bioavailability from Cereals: Current Strategies and Future Perspectives. Nutrition Bulletin, 43, 184188. https://doi.org/10.1111/nbu. 12324

[15] De Brier, N., Gomand, S.V., Donner, E., et al. (2016) Element Distribution and Iron Speciation in Mature Wheat Grains (Triticum aestivum L.) Using Synchrotron X-Ray Fluorescence Microscopy Mapping and X-Ray Absorption Near-Edge Structure (XANES) Imaging: Element Distribution and Iron Speciation in Wheat. Plant, Cell \& Environment, 39, 1835-1847. https://doi.org/10.1111/pce.12749

[16] Gemede, H.F., Haki, G.D., Beyene, F., et al. (2016) Proximate, Mineral, and Antinutrient Compositions of Indigenous Okra (Abelmoschus esculentus) Pod Accessions: Implications for Mineral Bioavailability. Food Science \& Nutrition, 4, 223-233. https://doi.org/10.1002/fsn3.282

[17] Winiarska-Mieczan, A., Zaricka, E., Kwiecień, M., et al. (2020) Can Cereal Products $\mathrm{Be}$ an Essential Source of $\mathrm{Ca}, \mathrm{Mg}$ and $\mathrm{K}$ in the Deficient Diets of Poles? Biological Trace Element Research, 195, 317-322. https://doi.org/10.1007/s12011-019-01826-Z 
[18] Mohapatra, D., Patel, A.S., Kar, A., et al. (2021) Effect of Different Processing Conditions on Essential Minerals and Heavy Metal Composition of Sorghum Grain. Journal of Food Processing and Preservation, 45, e14909. https://doi.org/10.1111/jfpp.14909

[19] Siminiuc, R. and Coșciug, L. (2021) Effect of Dehulling and Hydrothermal Treatment on the Amino Acid Content of Soriz (Sorghum oryzoidum). Food and Nutrition Sciences, 12, 1232-1242. https://doi.org/10.4236/fns.2021.1212090 